\title{
Alice Munro's Australian Mirror Stories
}

\begin{abstract}
Although Alice Munro is proverbially known to mythologize her home region of Southwestern Ontario, there are a handful of short stories that are set elsewhere where this elsewhere is not Vancouver, Canada. Two of these, though published twelve years apart, significantly take place in Brisbane, Australia, where Munro spent some time in the early 1980s. By carefully reading the two stories' plots, characters, and figuration, I argue two points: (1) The two stories are in fact each other's mirror images and that (2) although both shun the convention of the happy ending, the later text represents a more thoughtfully considered, mature critique of the female gothic romance rather than an excursion into comedy or a challenge to female fantasy as critical accounts suggested earlier. Reading the two narratives together and juxtaposing them with the Brontëesque tradition of the romance will eventually contribute to shifting the critical consensus about the unchanging concerns of Munro's fiction.
\end{abstract}

Key words

Alice Munro; Charlotte Brontë; Australia; romance plot; happy ending

Alice Munro, who received the Nobel Prize in Literature in 2013, is often identified with her native region, South-Western Ontario, Canada, because of her single-focused attention to life, women's life in particular, in this corner of the world. It is also often noted that only a few of her short stories are set elsewhere, and that this elsewhere is British Columbia, Canada. These, Sowesto (SouthWestern Ontario) as well as Victoria and Vancouver in British Columbia, are in fact the two places where Munro has lived her life and pursued a homemaker's career, first, then that of a bookstore owner's and, lastly but most successfully, of a writer's, which have thus constituted the locales for her fiction. And, indeed, of her more than one hundred narratives published at a surprisingly steady rate ever 
since the publication of her first volume of short stories in 1968, only a handful are set outside these places - significantly, two of them fully and one partly in Australia.

Quite conspicuously, not only are these two Australian stories special because they represent a most rare breakaway from the traditional Munrovian setting, but also because, although they are separated from each other by a twelve-year gap in writing, they function as one another's mirror images. In my discussion of "Bardon Bus" published in Moons of Jupiter in 1982 and "The Jack Randa Hotel" appearing in Munro's Open Secrets in 1994, I will argue that Charlotte Brontë's Jane Eyre provides the reflective surface accounting for the reversed images of the narratives; I will also claim that the latter Munro story is the carefully considered rewrite of the former as a result of the author's conscious reflection on themes central not only to these short stories in particular but to her fiction in general - namely, women's expectations of love, of their partners, of themselves. This reflection then led her to reformulate her critique of the Brontëesque romance fantasy already present in "Bardon Bus" but fully crystallizing by the time of writing "The Jack Randa Hotel." What somewhat complicates the discussion is that Australia serves as a mirror land to Canada at the very outset in both stories; but whereas in the earlier narrative it is a place where the protagonist is lost in love, in the latter one it is an elsewhere where self-recognition is not permanently denied to the love-lost heroine. As background to the discussion Munro's personal connection to Australia will be cited, as well as Coral Ann Howells, a leading Australian-born Munro critic's elucidation of "The Jack Randa Hotel" in addition to Marjorie Garson's study of Brontëesque themes in Munro's fiction. Also, my own discussion of Munro's neo-gothic re-appraisal of the Brontëesque romance fantasy will form a backdrop to explore Munro's re-evaluation of the romance notion of love in relationships whose pivotal setting is Brisbane.

\section{Munro and Australia}

Munro is customarily referred to as a regional writer and not only because the events of her fiction spanning over six decades proverbially take place in SouthWestern Ontario but also because she is known to be a rather reclusive writer unwilling to leave her home. After two decades of marriage spent in Vancouver and Victoria she returned to a small town just a few miles away from her birth place and only briefly traveled to Scotland to explore her family history (as it turned out she is a descendant of the Scottish writer James Hogg), to China (courtesy of PEN), and Australia. She in fact visited Australia three times: in the spring of 1979, in 1980, and 1983. In March 1979 she visited as the first Canadian recipient of the Canada-Australia Literary Prize administered by the Canada Council and the Australian Arts Council (Thacker 2011: 332). The award was given in alternating years to an English-language Canadian or Australian writer from 1976 to 1994 on the basis of the complete works of a writer. ${ }^{1}$ She then returned for an 
extended stay in 1980 as visiting writer at the University of Queensland (Thacker 2011: 374) in Brisbane, and for a holiday in 1983 (Thacker 2011: 265, 282) to Melbourne.

Strictly based on numbers, her travels do not seem to have greatly influenced her writing. There are references to Australia in one short story only, "Bardon Bus," published in her then most recent volume The Moons of Jupiter (1982) and in her most risky volume to date Open Secrets (1994) in two narratives, "The Jack Randa Hotel" and "Real Life." Numbers often cannot be trusted though, just as in this case, since critics quickly responded to all three narratives, emphasizing their importance in the context of the author's voluminous oeuvre (see Martin and Ober 1998; Howells 1996; Howells 1998). Also, Munro has referred to "Bardon Bus" several times, underlining its importance in her work.

Of her visits to Australia she said in an interview: "I enjoyed it [the visit] tremendously! Let's hope they [Australians] don't mind me saying this, but I found it very much like being on a mirror planet" (Boyce and Smith 1995: 231). The comparison rings especially true as in fact she portrays Australia as a mirror planet to her heroines, where things are ordinary, recognizable and familiar as well as strange because dislocated at the same time. Also, in these stories Australia both lies outside time and compresses time since it functions like a crossing in fairy tales, a temporarily suspended place where stories are shared, identities exchanged, provisional transformations completed.

\section{Setting in "Bardon Bus" and "The Jack Randa Hotel"}

In general, it can be stated that Gaston Bachelard's statement, "space contains compressed time. That is what space is for" (1994: 44) well encapsulates Munro's practice of portraying her settings. Though often labeled as a regionalist realist, she rarely writes extensive descriptions of her settings to create an effect of verisimilitude. Instead, she draws a historically layered portrait of them where there is a clear link between places and identity, transforming space into a process rather than a pre-existent given. This process, how a place appears to characters, is, however, largely modulated by the onlooker, the one who sees. This is why Munro's short stories could take place anywhere - there is hardly anything uniquely Canadian about them except for a few short stories. What is evoked instead is a sense of isolation, entrapment, wonder, astonishment or a plain lack of understanding among others registering characters' reactions to their particular settings when interacting with the world.

In "Bardon Bus," for instance, a story narrated retrospectively by its protagonist, a middle-aged female writer struggles with aging as well as with the memories of her last affair with a married man, another Canadian scholar, while in Australia. Here, the setting promptly becomes the exotic, lush backdrop for the heroine's probably last "sexual fling" (Rasporich 1990: 149). Brisbane is identified with its gullies filled with "jacaranda, poinciana, frangipani, cypress and 
palm trees. Leaves like fans, whips, feathers, plates; every bright, light, dark, dusty glossy shade of green. Guinea fowl lived down there, and flocks of rackety kookaburras took to the sky at dusk" (Munro 1991: 119). Even Queensland architecture, the "tongue-and-groove walls and the ventilation panels over the doors filled with graceful carved vines" (119) transform into signs of sexual passion. In fact, Australia as a whole becomes a metaphor for passionate abandon in a fantasy of love, whereas the return to Canada is post-coital emptiness. In "The Jack Randa Hotel," on the other hand, Brisbane is identified with the pale-skinned housewives shopping for groceries while hiding under wide-brimmed floppy hats. Trees "have tough-looking dusty foliage, scaly or stringy bark, a shabby ornamental air. An indifference or vague ill-will about them" (1995: 170) is what the similarly middle-aged protagonist, abandoned by her husband for a young Australian woman, notices. Correspondingly, bird life is described as "impudent" (177) rather than exuberant. ${ }^{2}$

The difference in the protagonists' perception of Australia derives from their attitudes rooted in their respective situations; this difference - emphatically portrayed as oppositional - is repeatedly reinforced in various ways in the narratives. Firstly, although both short stories focus on middle-aged women who decide to refashion themselves after their similarly middle-aged male partners start a new life with younger women, similarities stop here. While the unnamed narrator-protagonist of "Bardon Bus" hysterically throws herself into the world of department stores to attract the return of love by her new stylish looks as opposed to her earlier neglected self, Gail of "The Jack Randa Hotel" does just the opposite: she follows her husband to Brisbane and transforms into "somebody who has spent most of her life in uniform, at some worthy, poorly paid job [...] It is a disguise" (1995: 169). Secondly, in both stories Brisbane is an elsewhere: but whereas in "Bardon Bus" it is a place with a "holiday lightness of spirit" (113), for Gail it is a place of an anguished carnival where time stops. (It is telling in this respect that she does not want to believe that her beloved mother-in-law dies in Canada while she is in Australia since she expects time to stop while she is away.) Also, flora and fauna represent backdrop wonder for one (1991: 119), and deterrent for the other from "the real scene" (1995: 168). Fourthly, one corresponds with her ex-lover in her dreams, the other in reality - though she does so in the disguise of an elderly Australian namesake of her husband's; in addition, she even rents the apartment where the elderly lady lived until her death thus fully assuming the disguise she donned when setting out for the Antipodes. Furthermore, for one Australia is the place where her love affair eventually ends; for the other it offers a new beginning for love resting on a different footing. While in "Bardon Bus" the ambivalent ending, although ironic, holds no promise for the forlorn heroine - her lover has moved on to her younger friend - in "The Jack Randa Hotel" the equally ambiguous ending frees the heroine from her previous notions of love and relationships thus allowing for a new beginning. Lastly, in both stories there is a scene of gender confusion: in "Bardon Bus" the most beautiful and feminine character is a boy dressed in women's clothes and made up by shop assistants in a department store anxious to 
collect praise. "How do I look, momma?" asks the boy showing himself around to customers and shop assistants alike in the story (1991: 126). In "The Jack Randa Hotel," in turn, a big but boyish looking, shy, young man performs the everyday care of an old incapacitated man - a role traditionally associated with women. Gail believes them to be lovers. Thus, when reading the two stories against each other's backdrop, one can state that not only do they represent a mirror world to Canada, but their events and characters also are constructed according to the same logic though positioned at the distant ends of a spectrum.

\section{Parallel narratives, repetition, difference}

Although Munro has been identified with the short story as a genre, it has also often been noted that as a master of condensation she manages to convey full lives rather than just slices of them in her short narratives. For this effect she often uses parallel narratives as a form of repetition with a slight difference where the recognizable structural or thematic variations reflect upon each other: in "Bardon Bus," for instance, not only the protagonist's life is described in Australia and as its negative mirror image her life after her return in Canada; rather, she is also juxtaposed with her younger version, a good friend, in whose apartment she stays in Toronto. This friend, Kay, is characterized as follows: she "takes up a man and his story wholeheartedly. She learns his language, figuratively or literally," on her "shelves you can read a history of her love affairs" (Munro 1991: 116) as books on topics her former partners felt passionately about abound there. Ironically, or maybe not that ironically after all in line with the mirror image, Kay, the main character's younger version, falls in love with the same man the protagonist is trying to fall out of love from in the narrative.

Love is thus doubly defined as self-abandonment for and absorption in a man in "Bardon Bus," which is further underlined by the musings of the protagonist at the beginning of the narrative about her old single female relatives' life-long fantasies about love, which she describes as "a stubborn virgin's belief" in a "moment when you give yourself up, give yourself over, to the assault which is guaranteed to finish off everything you've been before" (111). That is, in the short story love appears as a state requiring women's total surrender three times. The differences in the female characters' life routes are used to underline the passing of time and the changing of mores. While the spinster sisters of earlier times are believed only to fantasize about love and the narrator-protagonist reticently, albeit increasingly visibly, responds to its ebb and flow, the younger Kay somewhat histrionically acts out the stages of her love affairs starting with new interests, culminating in new convictions and a new language, and finally leading to the end of enthrallment appeased with new interests again:

She takes up a man and his story wholeheartedly. She learns his language, figuratively or literally. At first she may try to disguise her condition, 
pretending to be prudent or ironic. "Last week I met a peculiar character-" or, "I had a funny conversation with a man at a party, did I tell you?" Soon a tremor, a sly flutter, an apologetic but stubborn smile. "Actually I'm afraid I've fallen for him, isn't that terrible?" Next time you see her she'll be in deep, going to fortune-tellers, slipping his name into every other sentence; with this mention of the name there will be a mushy sound to her voice, a casting down of the eyes, an air of cherished helplessness, appalling to behold. Then comes the onset of gloom, the doubts and anguish, the struggle either to free herself or to keep him from freeing himself; the messages left with answering services. Once she disguised herself as an old woman, with a gray wig and a tattered fur coat; she walked up and down, in the cold, outside the house of the woman she thought to be her supplanter. She will talk coldly, sensibly, wittily, about her mistake, and tell discreditable things she has gleaned about her lover, then make desperate phone calls. She will get drunk, and sign up for rolfing, swim therapy, gymnastics.

(Munro 1991: 116)

It is this repetition that prompts the narrator-protagonist to claim that: "The images, the language, of pornography and romance are alike; monotonous and mechanically seductive, quickly leading to despair" (123). And it is this definition of love as female fantasy that Munro challenges in "The Jack Randa Hotel" as a mirror story to "Bardon Bus," in which she consciously argues with the romance tradition.

\section{Jane Eyre and the romance plot}

As noted earlier, "The Jack Randa Hotel" appeared in Open Secrets, a volume that Munro called her riskiest one (Howells 1998: 120). ${ }^{3}$ The risks she takes in it partly concern her challenge to the female gothic romance tradition as solidified in the ultimate female gothic romance, Charlotte Brontë's Jane Eyre. As Marjorie Garson has demonstrated, Munro's fiction is profoundly influenced by Brontë's, especially by its representation of power positions in various relationships, the Jane/Bertha/Blanche pairing (2000: 784), and in their focus on epiphanic moments that allow for the heroines to extricate themselves from an essentially disadvantageous position (2000: 785). Garson also ventures to claim, "there have suddenly appeared in her stories groupings of figures who seem to be re-enacting, as in a dream, scenes one has witnessed before - scenes involving the ominous events that lead to the conclusion of Jane Eyre" (2000: 785).

She in fact succinctly summarizes the novel as the story in which little plain Jane successfully displaces the unrestrained (sexual/bad/big) woman by colluding "with the polite violence the father represents" (2000: 801). Garson also underlines that Munro understands in what ways this collusion in effect masks the heroine's "sinister will to power in Brontë's righteous little governess" (2000: 
801). These are themes that are equally present in "The Jack Randa Hotel" although in a slightly modified form: a plain Jane manages to regain an aloof middle-aged man's love interests after his affair with a young, exciting, and exotic (Australian) beauty only to show her power over him - and by extension over other women competing for his attention. Meanwhile, women continue to pit themselves against one another, and it is her intellect that wins him over rather than the other woman's beauty, sexuality, or wealth - the story thus becomes a complete middle-class fantasy.

In response to questions about literary influences, Munro has repeatedly expressed her admiration for an extensive list of authors and texts ranging from Victorian fiction and poetry to writers of the American South, including Jane Eyre; yet at the same time she has also confessed that she is unable to articulate in what ways they have influenced her own work. That in the case of "The Jack Randa Hotel" (which according to Martin and Ober could be rephrased as "The Randy Jack Hotel", 1998: 44) she has a particular author and text in mind can be argued with great confidence since the protagonist's philandering husband lives on Eyre Road in Brisbane. The text indeed lines up several themes and character types that Garson has identified as recurring ones from Jane Eyre in Munro's fiction.

Of the Brontëesque themes common to both stories there are many: in both there is a "plain Jane" (a middle-aged woman neglectful of her looks), who suddenly finds herself having to compete with at least one younger "dusky"4 beauty (Alex's wife and the narrator's friend, Kay in "Bardon Bus" and Sandy in "The Jack Randa Hotel") just as Jane had to compete with the exotic Bertha and beautiful Blanche. In both stories the male is emotionally distant; his motives are indecipherable for the heroines just as Mr. Rochester is known for his aloofness. In both the adults are so preoccupied with their love lives that the children are displaced just as Adèle's needs are constantly disregarded in Jane Eyre: in "Bardon Bus" both Alex and the protagonist-narrator have children but they are conveniently never mentioned; in "The Jack Randa Hotel" the reader learns that Gail had a baby who died of carbon-monoxide poisoning while she was living and traveling in a van as a hippie in her younger years. In both there is an attempt at spying: the heroine of "Bardon Bus" hopes to receive information about as well as to send a message to Alex through one of his friends, Dennis, whereas Gail literally spies on Will, even steals a letter of his only to enter into a correspondence with him under an alias, just like Mr. Rochester tricks the ladies by masking himself as a gypsy fortune teller or as Bertha walks around at night when she can outsmart her prison guard. In both the heroines seem to have a close connection to the spiritual world as they receive messages from a spiritual world in epiphanic moments (see the arrival at the Rivers' as well as the voice that calls Jane back to Thornfield): in "Bardon Bus" she dreams about the impossibility of communicating with Alex (in the dream the reader can overhear elements of the St. John Rivers and Jane Eyre relationship, as well as references to displaced children ${ }^{5}$ ), in "The Jack Randa Hotel" Gail receives several messages, which she however does 
not notice, so blinded is she by her mission to get at Will. Here is how she reacts when she first sees jacaranda trees in full bloom:

The flowers are a color that she has seen and could not have imagined on trees before- a shade of silvery blue, or silvery purple, so delicate and beautiful that you would think it would shock everything into quietness, into contemplation, but apparently it has not. (1995: 180)

But she attests to an equal lack of responsiveness in understanding the nature of the relationship between her neighbors, the big young man taking care of the older one: at first she believes them to be father and son, then she quickly jumps to assuming that they are lovers - this is why when asking the name of the tree in bloom she only hears "Jack Randa"/ "Randy Jack" (Martin and Ober 1998: 44). Even when the old man dies in the ambulance car, she believes him to hold on to her when in fact she holds on to him.

In short, she constantly misreads the world just like on another occasion - yet another parallel narrative to reinforce an idea through repetition - when earlier, still in Canada, she and Will saw thousands of yellow butterflies resting before continuing their long journey to South America. At the time she compared the sight to a biblical image - to its misreading, actually - it is like "the shower of gold" (Munro 1995: 184), she says. Upon which Will points out that the shower of gold is an image related to the myth of Danae's seduction by Zeus and is not to be confused with the Christian God's grace. Gail only sees what corresponds to her preconceptions: that love is what the world turns around, that love is a power struggle; and that she wants "randy" Will back in her life.

Another Brontëesque theme appearing in the short story is the way care is conceptualized: it appears in the framework of power. In Jane Eyre Grace Poole takes care of Bertha, where the care provider acts as a prison guard and the person under care as a prisoner (though Grace is as much imprisoned as her prisoner is). Similarly, the young man imprisons the older one in "The Jack Randa Hotel," but also escapes from his prison one day - in line with the mirror world, unlike Grace.

By extension, beauty care is likewise conceived of as a prison of socialization for women in "Bardon Bus," albeit one which women voluntarily. Kay, for instance, always dresses to the perceived expectations of her partners: for Alex she dresses in a "dark-green schoolgirl's tunic worn without a blouse or brassiere. She has dark-green knee socks and saddle oxfords." She even asks: "Does it look kinky?" (1991: 128) The narrator-protagonist enters the world of beauty care as a last resort in an effort to attract her former lover again. Gail in "The Jack Randa Hotel," in turn, gives up all her beauty routines to transform into a bodiless voice: she even hides in a dead woman's apartment ventriloquizing the imagined voice of an elderly lady dissatisfied with the ways of the world recently in letters to Will. She becomes her own mirror image in Australia; she is now Mrs. Massie from Oklahoma, dressed "like the other women she sees on the street. 
Housewives, middle-aged, with bare but pale arms and legs, shopping in the early morning or late afternoon. She bought a floppy straw hat too, to shade her face as the women do. Dim, soft, freckly, blinking faces" (Munro 1995: 174). But when she writes to Will, she impersonates a library woman, who "wears a hairnet and gray lisle stockings in spite of the heat. [...] She has an undernourished body and colorless, tight, unsmiling lips. She is the person Gail calls to mind when she writes the letter from Catherine Thornaby" (1995: 175).

According to Howells, Moons of Jupiter, with "Bardon Bus" in it, represents a significant turning point in Munro's fiction not only because here she developed new ways of writing the passage of time but also because "patriarchal figures are often discredited, while traditionally feminine positions are shown to be restrictive and damaging or at best cherished romantic illusions" (Howells 1998: 71). What is shown as a "cherished illusion" in "Bardon Bus" - the notion of allencompassing love as the most important goal of women's life and the myth of empowering beauty - is somewhat ironically and apologetically presented in the narrative. The narrator-protagonist's and her friend Kay's successive immersion in what they consider love - the "stubborn virgin's belief" - appears as the natural course of women's life. Of Kay, she writes:

When love is fresh and on the rise she grows mystical, tentative; in the time of love's decline, and past the worst of it, she is brisk and entertaining, straightforward, analytical. (1991: 117)

In none of this is she so exceptional. She does what women do. Perhaps she does it more often, more openly, just a bit more ill-advisedly, and more fervently. Her powers of recovery, her faith, are never exhausted. (1991: 116)

It is in this context that the reversed, mirror, images of "The Jack Randa Hotel" assume a great significance and defy all possible claims about writers' efforts to shift creative powers into high gear again. Gail's decision to dress down rather than up, to ventriloquize a prim elderly lady in her letters rather than to impersonate a schoolgirl, and finally to escape from Will just when he seems ready to tire of his "May-December" relationship in the Antipode and to get back to her gains its significance through its rejection of women's traditional positions (the love-lost forlorn woman, the vengeful jilted ex), as well as the rejection of those cherished romantic illusions.

What Munro discredits through Gail's decisions is the idea of the Brontëesque romance between plain Jane and the aloof two-faced hero for whose favors she has to pit herself against the beautiful, the young, the privileged, and his as well as her past altogether. In Jane Eyre romance is conceived as a power struggle which ideally culminates in the formation of a companionate family of two (him and her), where, however, eventually and ideally, he will depend on her. Brontë invented the device of wounding the hero to give novelistic credibility to his dependence on her: Mr. Rochester is disfigured by fire, whereas Jane becomes heir to a fortune. In "Bardon Bus" Munro's focus falls on women's willingness to 
enter the power struggle as Blanche Ingram does: by appealing to men's aesthetic sense. Women however can only lose this way since aging holds very different promises and possibilities for men and women. In "The Jack Randa Hotel" Munro challenges the very idyll of the Brontëesque companionate family of male dependence. Instead, she closes the narrative when Gail opts out of the romance by flying back to Canada and sending a turtle figurine helplessly lying on its back with a note enclosed that encourages Will to continue their game of hide and seek back at home. It is not the seeming stasis of companionship expressed through the convention of the happy ending that she seeks.

\section{Conclusion}

"The Jack Randa Hotel" is in many ways a curious story within the Munro oeuvre, and, yet it is also vintage Munro. Although it continues to recycle themes familiar in her fiction, it also ventures on new territory in at least two ways: its heroine travels outside Canada as far away as Australia - a rare event in Munro's stories - and she opts out of the romance plot. Also, it does not only hold up a mirror to "Bardon Bus," in which the protagonist tries to break out from her role of plain Jane, but via its intertextual references it also interrogates the Brontëesque female gothic romance with its insistence on one particular understanding of the happy ending, which Gail rejects. In a sobering visionary - epiphanic - moment she realizes that: "Words most wished for can change. [...] words can become a din, a battering, a sound of hammers in the street. And all you can do is run away, so as not to honor them out of habit" (1995: 188). The only place where such sobering is possible is an elsewhere, a mirror world magically different and yet familiar: Australia.

\section{Notes}

1 The list of recipients is impressive: besides Munro, Michael Ondaatje, Mavis Gallant, Audrey Thomas, and Rohinton Mistry were awarded it in Canada, and Louis Nowra, Georgia Savage, Elizabeth Jolley, Rodney Hall, Les A. Murray, Barry Oakley, Roger McDonald, Thomas Schapcott, and John Romeril in Australia.

2 "In-between the ridges, which the houses cling to, there are steep-sided gullies full of birds and trees. Even as the sun grows hot, those birds are not quiet. Magpies keep up their disquieting conversation and sometimes emerge to make menacing flights at her light-colored hat. The birds with the name like her own cry out foolishly as they rise and whirl about and subside into the leaves. She walks still she is dazed and sweaty and afraid of sunstroke. She shivers in the heat-most fearful, most desirous, of seeing Will's utterly familiar figure, that one rather small and jaunty, free-striding package, of all that could pain or appease her, in the world" (Munro 1995: 180).

3 "It's pointless to go on if you don't take risks. While the stories in Open Secrets have elements of mystery and romance for example, themes which have always attracted readers, they do not satisfy in the same way as a traditional mystery or romance would. As I stated earlier, I wanted these stories to be open. I wanted to challenge what people want to know. Or expect to know. Or anticipate knowing. And as profoundly, what I think I know" (Munro qtd. in Howells 1998: 120). 
This is how Kay aspires to look. Alex's wife studies music in India. Gail imagines Sandy as an exotic beauty.

"I dreamed that X wrote me a letter. It was all done in clumsy block printing and I thought, that's to disguise his handwriting, that's clever. But I had great trouble reading it. He said he wanted to go on a trip to Cuba. He said the trip had been offered to him by a clergyman he met in a bar. I wondered if the clergyman might be a spy. He said we could go skiing in Vermont. He said he did not want to interfere with my life but he did want to shelter me. I loved that word. But the complications of the dream multiplied. The letter had been delayed. I tried to phone him and I couldn't get the telephone dial to work. Also it seemed I had the responsibility of a baby, asleep in a dresser drawer. Things got more and more tangled and dreary, until I woke" (Munro 1991: 114).

\section{References}

Bachelard, Gaston (1994) The Poetics of Space. Boston: Beacon Press.

Boyce, Pleuke and Ron Smith (1995) "A national treasure. Interview with Alice Munro.” Meanjin 54 (2): 222-232.

Garson, Marjorie (2000) “Alice Munro and Charlotte Bronte.” University of Toronto Quarterly 69 (4): 783-825.

Howells, Coral Ann (1996) “Taking Risks: Alice Munro's 'The Jack Randa Hotel'.” In: Jelinek, Hena Maes, Gordon Collier, and Geoffrey V. Davis (eds.) A Talent(ed) Digger: Creations, Cameos, and Essays in Honour of Anna Rutherford. Amsterdam: Rodopi, 387-393.

Howells, Coral Ann (1998) Alice Munro. Manchester: University of Manchester Press.

Martin, Walter R. and Warren U. Ober (1998) "The Comic Spirit in Alice Munro's Open Secrets: 'A Real Life' and 'The Jack Randa Hotel'." Short Studies in Fiction 35 (1): 41-47.

Munro, Alice (1991) “Bardon Bus.” In: Munro, Alice. The Moons of Jupiter. New York: Vintage, $110-128$.

Munro, Alice (1995) "Real Life.” In: Munro, Alice. Open Secrets. London: Vintage, 52-80.

Munro, Alice (1995) “The Jack Randa Hotel.” In: Munro, Alice. Open Secrets. London: Vintage, 161-189.

Rasporich, Beverly J. (1990) Dance of the Sexes: Art and Gender in the Fiction of Alice Munro. Edmonton: University of Alberta Press.

Szabó, Andrea F. (2010) Alice Munro's Neo-Gothic: Short Stories from the 1990s. Dissertation. Debrecen: University of Debrecen.

Thacker, Robert (2011) Alice Munro: Writing Her Lives: A Biography. Toronto: McClelland \& Stewart.

Andrea F. Szabó, PhD, is senior assistant professor at the English and American Studies Institute, University of Pannonia, where she teaches courses in North-American literature and culture. She specializes in American and Canadian women's literature as well as the Gothic. Her research interests include the intersections of literature and gender, those of Gothic Studies, the Female Gothic in particular, and Spatiality Studies, as well as, Alice Munro's fiction, which embraces all of the above. She is founding co-editor of TOPOS - Bilingual Journal of Space and Humanities.

Address: Dr. Andrea F. Szabó, Institute of English and American Studies, Faculty of Modern Philology and Social Sciences, University of Pannonia, 10 Egyetem Street, H-8200 Veszprém, Hungary. [szabofa@almos.uni-pannon.hu] 
